\title{
7 CHE RECEPTION OF KNUT HAMSUN IN ROMANIA IN THE PERIOD 1919-1926
}

\section{Diana Lățug}

Babeş-Bolyai University, Cluj-Napoca, E-mail: dianalatug@gmail.com

\section{Acknowledgements}

This paper has been presented at the Fourth international conference on Baltic and Nordic Studies in Romania Empire-building and Region-building in the Baltic, North and Black sea areas hosted by the Romanian Association for Baltic and Nordic Studies and Ovidius University of Constanta, May 24-26, 2013. Supported by a grant from Iceland, Liechtenstein and Norway (Finantat prin fonduri donate de Islanda, Liechtenstein si Norvegia).

\begin{abstract}
:
The present paper presents the Norwegian author Knut Hamsun as he has been perceived in the Romanian literary and cultural frame between 1919-1926. Such a work intends to do research upon relevant articles written in this period. His positioning as a well-established predecessor within the modernist European literary framing is empowered by biographical information to be found in abundance in a wide range of literary specialized magazines. Among them, "Adevărul Literar şi Artistic", "Sburătorul Literar", „Viața Literară", or "Viața Românescă". The work is structured on a chronological overview of his reception in the Romanian culture from the interwar period. The novels whose reviews were shortly mentioned are "Pan", "Victoria" and 'Hunger". The translators are also to be mentioned, given the fact that they are outstanding figures for the Romanian culture. The biographical details concern his winning of the Nobel Prize in 1920, and how this was perceived by the Romanian literary critics. More precisely, if there is any shift in the perception of the author before and after the Nobel award.
\end{abstract}

\section{Rezumat:}

Lucrarea de față îl prezintă pe autorul norvegian Knut Hamsun aşa cum a fost perceput în contextul literar și cultural românesc al anilor 1919-1926. Intenționăm cercetări ale articolelor relevante scrise în această perioadă. Poziționarea sa ca un predecesor al modernismului european este împuternicită de informații biografice 
apărute într-o gamă largă de reviste literare de specialitate. Printre ele, "Adevărul literar și artistic", "Sburătorul literar", "Viața literară" sau "Viața Românească". Lucrarea este structurată pe o prezentare cronologică a receptării sale in cultura românească din perioada interbelică. Romanele la ale căror recenzii se face referire sunt "Pan", ,Victoria" și „Foamea”. Traducătorii trebuie de asemenea menționați, dat fiind faptul că sunt figuri de marcă pentru cultura românească. Detaliile biografice au de a face cu câş̧tigarea Premiului Nobel in 1920 și cu modul în care acest lucru a fost perceput de către criticii literari români. Mai exact, dacă se produce vreo schimbare în percepția autorului înainte și după Premiul Nobel.

Keywords: Nobel Prize winner, interwar period, biography, review, translations, Romanian culture, periodical

Who could be "the best Norwegian writer" 1 [our translation], the one who wrote Pan and Hunger, "a massive writer who was awarded the Nobel Prize three years ago"2 [our translation]? Characterized by having "an optimism and an exceptionally contemplative serenity among Nordics"3 [our translation], he is also "opponent to Ibsen's work"4 [our translation]. Knut Hamsun is the only name that could join together so many controversial representations in a foreign culture.

Starting with the $20^{\text {th }}$ century, Knut Hamsun was considered to be one of the best novelists in Europe. Even though during World War II he was associated with the Norwegian Nationalistic Party and was accused of treason at the end of the war, in 1945, his writings remained masterpieces, clear of any political ideology. Nowadays, regardless of what his political inclinations might have been, Knut Hamsun is one of the most appreciated authors in Norway.

Furthermore, he is a forerunner of the stream of consciousness technique which he promoted in his novel Hunger, published in June 1890. Modernist characteristics such as solitude, estrangement, revolt against the

1 „Knut Hamsun - Însemnări,” Adevărul Literar şi Artistic, nr. 1 (1920): 4. „cel mai bun scriitor norvegian".

2 Demostene Botez, „Knut Hamsun: Victoria,” Opinia, nr. 4719 (1923): 1. „scriitorul masiv care a primit premiul Nobel acum trei ani".

3 A. Dominic, „Knut Hamsun. Portrete străine,” Mişcarea Literară, nr. 9 (1925): 1. „optimism şi o seninătate contemplativă de excepție printre nordici".

4 „Knut Hamsun. Cărți, idei, oameni,” România Nouă, nr. 7 (1921): 4. „un adversar al operei ibseniene". 
society and against the divinity are concepts that support its positioning as the first modernist novel in Norway. He thus redefined the concept of the novel not only in Norwegian literature but also in world literature, being considered the first modernist novelist in Norway.

Before publishing Hunger he theorized upon a new type of literature in his programmatic article, From the Unconscious Life of the Soul (Fra det ubevidste sjeleliv). In his 1890 manifesto, he insisted as well on creating a literature centred upon the individual, that is a psychological literature. That was due to the fact that the psychic activity was considered too delicate to be communicated through already existing literary techniques, namely the typologies imposed by the realistic trend. He thus focuses not only on the way they act under the pressures of the environment, but also on understanding what happens in the mind of his characters: "What if literature would finally start investigating a little closer psychical states?"5 [our translation].

What I intend in this paper is to provide an overview of his reception in various Romanian literary periodicals in the period from 1919 to 1926.

Starting from the above mentioned premise, the main topic of my paper is to offer a general perspective of his influence in the Romanian cultural life as presented in this precise period. Biographical and bibliographical details before and after he received the Nobel Prize for literature support this thesis. Furthermore, I shall also make reference to some reviews of the translations that primarily entered the Romanian literary market. The work was based on a close reading of articles in old periodicals, followed by a critical interpretation. The access to all these articles has been considerably eased by a bibliography investigating the relations of the Romanian literature with foreign literatures, in periodicals, for the period 1919-1944. It contains clear and concise bibliographical information in order to find the article directly

To begin with, one should analyze Knut Hamsun's recognition as a Nobel Prize winner, by mentioning that he was one of the most prominent Norwegian writers of his time and one of the three Norwegian Nobel laureates in literature. Hamsun is considered one of the foremost

\footnotetext{
${ }^{5}$ Knut Hamsun, "Fra det ubevidste sjæleliv," Samtiden, June, 1890. "Hvad om nu Litteraturen i det hele taget begynte at beskæftige sig lidt mere med sjælelige Tilstande...?".

6 Ana-Maria Brezuleanu et al., Bibliografia relațiilor literaturii române cu literaturile străine în periodice (1919 - 1944), vol. III (Bucureşti: Ed. Saeculum I.O., 2000).
} 
representatives of neo-romanticism in Norway. He was unhappy with the way realism portrayed stereotypes within people and would put emotion in the centre. This stood at the basis of writing a new type of literature with psychological insights?.

There are of course many articles in the cultural area of early $20^{\text {th }}$ century illustrating his award. Before dealing with them, it is important to note articles denying his awarding of the Nobel in 1920. One of them is in Luceafărul at the very beginning of the reference year: $1^{\text {st }}$ February $1920^{8}$.

In any case, the year 1919 highlights his reputation as a literary personality: "A social writer with deep psychological insights"9 [our translation], bearing all the hallmarks of the Nordic style. Thus, in magazines such as Patria, Adevărul or Sburătorul Literar, to name just a few, there was information about the person who had written Hunger and Pan, and who now had achieved a successful position. Whether there are clear references to Hamsun as a Nobel Prize winner, or just comments on his writing, one thing is for sure: the Norwegian author became representative in the European context, beginning with the first part of the 1900s and until today.

Indicative of Hamsun's reception on the Romanian literary market is a chronological overview of articles from literary periodicals. Insemnări literare from 1919 contains an article where Mihai Ralea states that Hamsun had just been awarded the Nobel Prize: "An art researcher could classify contemporary literature in two main sections: Nordic literature and European literature. The Nordic point of view is different, having other ethics concepts, actions. In this respect, the most representative is today's Nobel Prize winner, Knut Hamsun [....] Knut Hamsun is a cultivated primitive. [...] With a modest start, Knut Hamsun has received enough culture to disturb the mind, without satisfying it. His life, unimaginably varied, is the obsession of a bewildered." 10 [our translation].

\footnotetext{
7 Roar Lars Langslet, Hamsun. Det skiftende spillets dikter (Oslo: Aventura Forlag, 1996), 58.

8 „Premiul Nobel pe 1919 - Cronică. Însemnări," Luceafărul, nr. 2-3 (1920): 48.

9 C. Săteanu, „Knut Hamsun: Păreri şi fapte,” Mişcarea, nr. 171 (1919): 1. „scriitor social şi profund psiholog".

10 Mihai Ralea, „Knut Hamsun. Portret literar,” Însemnări Literare, nr. 33 (1919): 13. „Un geometru în ale artei ar putea clasifica literatura contemporană în două mari capitole: literatura europeană şi literatura nordică. Punctul de vedere nordic e altul; altele sunt moravurile concepțiile, acțiunile. În privința aceasta cel mai reprezentativ tip e premiantul Nobel de azi, Knut Hamsun [....] Knut Hamsun e un primitiv cultivat. [...] Pornit de jos, Knut Hamsun a primit atâta cultură cât poate tulbura o minte, fără s'o satisfacă. Viața sa, de o varietate neînchipuită, e obsesia unui dezorientat".
} 
1921 is characterized by substantial reviews after the first translation of Pan, not directly from Norwegian, but from German. Prior to analyzing them, I shall portray a biographical background, influenced by the breakthrough with this novel. "I swear to God I'm going to write an extraordinary book now, just trust me, I'm really into it. [...] Oh, I've got something in my mind! Bolette Larsen, may God punish me if I don't amaze you a bit next time with my book from Nordland. As it will be beautiful!11" [our translation]

And it was a beautiful book indeed! "Your book is natural and simple, like cherries in the summer"12 [our translation]. A presentation of an unmentioned author appeared in Cuvântul literar, Bucharest, shortly after Ion Luca Caragiale's translation of Pan. He is the first to translate this novel, but through a contact culture, namely German. The article is entitled Din străinătate (From abroad). ${ }^{13}$ A wider presentation - this time of the author's originality was written by Adrian Drăgoescu in Adevărul literar şi Artistic. ${ }^{14}$ A review that I find worth mentioning at this point is from Sburătorul literar, written by Mihail Iorgulescu. Pan is characterized as: "A good book, with a bad translation. Luca I. Caragiale is to be praised for kind intentions of spreading Scandinavian literature. The final result unfortunately overshadows his remembrance. [...] The diary form accurately describes the sufferings of a primitive soul, with almost wild outbursts, but in fact of a completely modern refinement."15 [our translation].

Hence, it is the first time that the book's primary translation is criticized, although Caragiale's work shall remain a standpoint for many other literary analyses hitherto. Some of them will also be referred to during the current study.

\footnotetext{
11 Hamsun til Larsen 31.10, 12.11 and 23.11.93, qtd. in Ingar Sletten Kolloen, Hamsun Erobreren (Pössneck: Gyldendal Norsk Forlag, 2005), 190. “Jeg skal ved Gud i Himmelen skrive en underlig og inderlig bok nu, tro mig, bare, jeg er aldeles omtåget av den. [...] $\mathrm{A}$, jeg har noget i hovedet! Bolette Larsen, jeg skal så Gud straffe mig forundre Dere lidt næste gang med min bog fra Nordland. For den skal blive vakker".

12 B. Fundoianu, „Knut Hamsun, Pan, traducere de Ion Luca Caragiale,” Rampa Nouă Ilustrată, nr. 987(1921): 1. "Cartea ta e firească şi simplă, cum sunt vişinii vara”.

13 „Pan, de Knut Hamsun," Cuvântul Literar, 1, nr. 2 (1921): 29.

14 Adrian Drăgoescu, „Knut Hamsun, Pan,” Adevărul Literar şi Artistic, nr. 16 (1921): 4.

${ }_{15}$ Mihail Iorgulescu, „Knut Hamsun, Pan,” Sburătorul Literar, nr. 1 (1921): 20. „O carte bună, tradusă rău. Luca I. Caragiale merită laude pentru frumoasele intenții de a răspândi literatura scandinavă. Executarea intențiilor sale e însă o pată pe amintirea lui. [...] În formă de jurnal sunt prinse cu fidelitate suferințele unui suflet de o primitiviate şi candoare aproape sălbatecă în manifestări, în fond însă de o rafinerie cu totul modernă".
} 
Pan is not the only novel to be reviewed in 1921. Victoria is described as "a romance novel written by a modern writer." 16 [our translation]. Markens Grøde (The Growth of the Soil), translated as Cultura Pământului is presented as the last work, with "literary, social and moral value."17 [our translation]. An advised reader, who knows the original language, will certainly contradict with this title, but this is a totally different topic.

One year later, in 1922 Adrian Drăgoescu published in Flacăra, Bucharest an article in which he is an advocate of the author's originality: "The originality in portraying characters, the positivism used for emphasizing such a veridical state of mind [...] such a representative and vibrant description of ordinary life ... "18 [our translation].

Cora Irineu wrote a review of Pan in Viața Românească from 1922, two years after the book appeared at a publishing house with the same name, in Caragiale's translation. Petre Pandreal Marcu is the one who in 1923 started the series of Hamsun articles with, again, an appreciative review of Pan. By providing multiple quotes from Caragiale's translation, he tries to explain what nature means for the Norwegian author. Furthermore, he deals with Knust Hamsun's style (perhaps this extra $s$ is just a misprint). "Hamsun's Return to nature is not a romantic refuge, [...] since Nature is for him a reality he can live in, the necessary ambience where the soul can exist and have a resonance. [...] Hamsun is hopelessly antisocial."19 [our translation].

As aforementioned, not only Pan has been more or less criticized, but also Victoria, to some extent. Silvan Lorin's translation has received a negative commentary, as it stands against a standardized Romanian language: "From a certain point, the literary world, convinced of the great gap that can be filled with translations of universal literary works, rightly turned their attention towards them. [...] It was precisely because these productions were necessary, well received and rewarded enough [...] all

\footnotetext{
16 „Knut Hamsun, Victoria," Adevărul Literar şi Artistic, nr. 19 (1921): 4. „roman de dragoste, scris de un autor la modă".

17 „Ultima operă a lui Knut Hamsun,” Opinia, nr. 4370 (1921): 1. „valoare literară, socială şi morală".

18 Adrian Drăgoescu, „Knut Hamsun. Din neguri scandinave," Flacăra, nr. 15 (1922): 236. „originalitatea cu care schițează caracterele, pozitivismul cu care subliniază starea sufletească atât de veridică [...] descrierea atât de reprezentativă şi vibrantă a vieții ordinare...."

19 P. Marcu, „Pan, de Knut Hamsun. Aspecte contemporane,“ Flacăra, nr. 6 (1923): 115. „Reîntoarcerea la natură a lui Hamsun nu este un refugiu romantic, [...] ci Natura pentru el este o realitate în care poate trăi, ambianță necesară unde sufletul poate exista şi poate avea o rezonanță. [...] Hamsun este iremediabil nesociabil."
} 
those who know to look up in a foreign dictionary and are still able to link two crippled phrases in Romanian felt themselves obliged to darken a world personality, mutilating it as barbaric as possible and claiming as their last excuse: our language is poor! [...] the whole book is completely antiRomanian, translated thoroughly unaesthetic. Poor Knut Hamsun, poor Victoria! Poor Romanian language!" 20 [our translation].

It seems that the great number of attempts to analyze Hamsun makes it difficult to coherently choose what should be mentioned and what should be left aside, him being an author who presents the deepest thoughts of his characters in such a way that: "He himself is surprised by their behaviour, just like us." 21 [our translation].

Given the fact that the intention in this paper is to focus on a particular period, I have also chosen to limit the investigation at presenting the reception of only a few of his books. These were, until now, Pan and Victoria. Hunger comes next, thus 1924 as another representative year for Hamsun's reception. Enric Furtună is a Romanian poet and playwright. He is important as he was one of the first to review Hunger: "The novel entitled Hunger is undoubtedly an autobiographical one: an artistic and meaningful confession of Knut Hamsun's years of poverty. But this horrible poverty is overcome by the pride and dignity of a human nature aware of its superior essence [...]. Through its unparalleled art, this novel arrays Knut Hamsun (the author of Pan) among the greatest masters of writing and of the poor human soul." 22 [our translation].

20 C. Mihăilescu, "Traducerile - cu prilejul Victoriei de Knut Hamsun," Clipa (Bucureşti) nr. 28 (1923): 1. „Dela o vreme, lumea literară, convinsă de golul cel mare pe care îl umple traducerile capod'operilor universale, au îndreptat, pe bună dreptate, toate atențiile înspre ele [...] Tocmai pentru că aceste producții au fost necesare, bine primite şi răsplătite îndeajuns [...] toți câți ştiu să caute într'un dicționar străin şi mai pot să lege două fraze schiloade în româneşte, s'au simțit obligați să întunece câte o personalitate mondială, mutilând-o, cum nu se poate mai barbar şi găsind ca ultimă scuză: limba noastră e săracă! [...] Cartea e întreagă antiromânească, complet inestetic tradusă. Bietul Knut Hamsun, sărmana Victoria! Biata limbå românească!"

21 Tudor Ispravă, „Ultimul capitol, noul roman al lui Knut Hamsun,” Dreptatea (Chişinău) nr. 98 (1924): 2. „şi Hamsun se miră el însuşi de purtarea lor tot aşa de mult ca şi noi."

22 Enric Furtună, „O spovedanie artistică," Lumea (Iaşi) nr. 3 (1924): 6. „Romanul intitulat Foamea e, fără îndoială, de natură autobiografică: o spovedanie artistică şi plină de tâlc din anii de sărăcie ai lui Knut Hamsun. Această oribilă sărăcie însă este biruită de mândria şi demnitatea unei firi conştiente de esența ei superioară [...] Prin arta lui incomparabilă, romanul acesta rândueşte pe Knut Hamsun (autorul lui Pan) între cei mai zguduitori meşteri ai scrisului şi-al bietului suflet omenesc." 
An article from 1925 states that Hamsun was born in 1860 in a Norwegian village. ${ }^{23}$ One could drop such a harsh criticism (as Hamsun was born in 1859), if taking into account that the primary dates could have been mistaken since the attention was on the authorship and not on the years. For those not knowing that Hamsun was "a limited, unsociable spirit [...] misanthrope" 24 [our translation], this image will remain in their minds after reading the article. The same person is the one who in his late years "clings to his habits from misery times: when he received a yellow watch as a gift, he did not know what to do with it. He had another one, made of nickel!" [our translation].

Om hundrere år er alting glemt (In One Hundred Years Time, Everything Is Forgotten), is the title of one of his poems. But within six years from winning the Nobel, he was not forgotten at all. 1926 might be called as another reference year for the Romanian literary field. Firstly, because one finds in two different periodicals from that same year references to a coming publication of Sult (Hunger). From a French translation, purportedly: "French newspapers announce the translation of Hamsun's Hunger. Thus, the reading of the most heartbreaking tragedy of mankind will be open to our public." 25 [our translation].

All these quotes do nothing but express the same idea in many words, namely that Hunger had a great impact in Romania, as it had worldwide. It was a book expected with curiosity by the Romanian public, thanks to its socalled autobiographical character. Ion Pas provides an overview of the novel, by pointing out that there is a proper relationship between creativity and misery in the act of writing. His review plays an important role as he is the first to translate the novel in Romanian. "It is announced that Knut Hamsun's Hunger shall appear in Romanian, as well. [...] This literary work is and will remain forever shocking because it's written with extraordinary sincerity. The novel's hero is the Scandinavian writer himself, whom life has not caressed at the beginning, as it has not caressed that impressive legion of

23 „Însemnările săptămânii - Knut Hamsun,” Cuvântul Literar şi Artistic, nr. 5 (1925): 4. „Născut la 1860, într'un sat norvegian..."

24 Ibidem. „spirit mărginit, lipsit de sociabilitate [...] mizantrop [...] bătrân, îşi păstrează încă apucăturile sale din timpurile de mizerie: când i s-a făcut cadou un ceas de aur n'a ştiut ce să facă cu dânsul. Avea altul, de nichel!"

${ }^{25}$ C. Narly, „Knut Hamsun,” Viața Literară, nr. 4 (1926): 3. „Ziarele franceze anunță traducerea Foamei lui Hamsun. Astfel va fi accesibilă şi publicului nostru lectura celei mai sfâşietoare tragedii omeneşti."

154 
writers whose biography itself seems an excerpt of untrustworthy literature. [...] Elements of the author's life overlap with those of the book's hero. This is why this book shocks, from its first to its last page, and because it is written so sincerely, despising any literary contrivance, it remains unique in the universal literature." 26 [our translation].

Two more reviews were written in 1926 in periodicals like Clopotul and Cultura Proletară, in order to strengthen the novel's impact. Both of them came out in October, the first at the beginning of the month and the other in the middle of the month.

I have decided not to end up with 1926, but to go on further at something written in 1929, that is, when the Norwegian author became seventy. He is still portrayed as "a misanthrope, a solitary. When he was awarded the Nobel Prize, he was asked about the way he wanted people to be like. He answered: They should be good people, able to sacrifice themselves for home and children. There is nothing more you can ask them ${ }^{27}$ [our translation].

Was Knut Hamsun really a solitary and a misanthrope person? Yes, he was lonely in trying to explain as many unknown aspects of our behaviour, offering a valuable piece of writing to readers all over the world. The Romanian readers can as well have access to Hamsun's universe through the work of Ion Luca Caragiale or Ion Pas. Mihai Ralea, Cora Irineu, Demostene Botez or Enric Furtună, to mention the authors of only a few articles, have been advocates of Hamsun's mastery, acknowledged also nowadays. This aura of success around Hamsun may be explained by his winning of the Nobel Prize in 1920. But this positive reception shall only last until the 1940s, when there is a huge shift in his image in Romania and the

\footnotetext{
26 Ion Pas, „Foamea," Lupta, nr. 1372 (1926) : 1. „Se anunță că va apare şi în româneşte Foamea lui Knut Hamsun [...] Opera a rămas şi va rămâne de-a pururi zguduitoare căci e scrisă cu extraordinară sinceritate. Eroul romanului e însuşi scriitorul scandinav pe care viața nu l-a dezmierdat la început cum n'a dezmierdat acea impresionantă legiune de scriitori a căror biografie ni se pare ea însăşi o pagină de literatură neverosimilă. [...] Elementele vieții autorului se confundă cu ale eroului din carte. De aceea cartea zgudue dela prima la cea din urmă pagină, - iar pentru că e scrisă cu desăvârşită sinceritate, în disprețul ori cărei preocupări de artificiu literar, ea rămăne fără echivalent în literatura universală."

27 „La 4 august scriitorul norvegian împlineşte 70 de ani,” Gazeta Noastră, nr. 87 (1929): 9. „a rămas în fond un mizantrop, un singuratic. Când i se atribui Premiul Nobel, fu întrebat cum ar dori să fie oamenii. Răspunse: Să fie buni şi să se sacrifice pentru cămin şi copii. Mai mult nu le potic cere".
} 
entire world, because of his Nazi sympathies. Since this is not the subject of this paper, it shall be investigated in further studies.

To conclude, his reception in the first years of the 1920s denotes a growing interest in his work combined with a positive attitude on his activity. It is one of Hamsun's greatest periods of reception in Romania.

\section{References}

\section{Books and periodical articles}

Botez, Demostene. „Knut Hamsun: Victoria.” Opinia, vol. XIX, no. 4719, Feb. 18 (1923): 1.

Brezuleanu, Ana-Maria, Ileana Mihăilă, Viorica Hişcov, Michaela Şchiopu, Cornelia Ştefănescu. Bibliografia relațiilor literaturii române cu literaturile străine în periodice (1919 - 1944). vol. III. Bucureşti: Ed. Saeculum I.O., 2000.

Dominic, A. „Knut Hamsun. Portrete străine.” Mişcarea Literară, vol. II, no. Jan. 9, 10 (1925): 1.

Drăgoescu, Adrian. „Knut Hamsun, Pan.” Adevărul Literar şi Artistic, vol. II, no. 16, Mar. 13 (1921): 4.

Drăgoescu, Adrian. „Knut Hamsun. Din neguri scandinave.” Flacăra, vol. VII, no. 15, Mar. 18 (1922): 236.

Fundoianu, B. „Knut Hamsun, Pan, traducere de Ion Luca Caragiale.” Rampa Nouă Ilustrată, vol. V, no. 987, Feb. 11 (1921): 1.

Furtună, Enric. „O spovedanie artistică.” Lumea (Iaşi), vol. I, no. 3, Nov. 16 (1924): 6.

Iorgulescu, Mihail. „Knut Hamsun, Pan.” Sburătorul Literar, vol. I, no. 1, Sept. 17 (1921): 20.

Irineu, Cora. „Knut Hamsun. Pan tradus de Luca Ion Caragiale.” Viața Românească, vol. XIV, no. 3, Mar. (1922): 467.

Ispravă, Tudor. „Ultimul capitol, noul roman al lui Knut Hamsun.” Dreptatea (Chişinău), vol. IV, no. 983, Apr. 13 (1924): 2.

„Însemnările săptămânii - Knut Hamsun.” Cuvântul Literar şi Artistic, vol. II, no. 5, Feb. 1 (1925): 4.

„Knut Hamsun. Cărți, idei, oameni.” România Nouă, vol. II, no. 7, Mar. 13 (1921): 4.

„Knut Hamsun - Însemnări." Adevărul Literar şi Artistic, vol. I, second series, no. 1, Nov. 28 (1920): 4. 
„Knut Hamsun, Victoria.” Adevărul Literar şi Artistic, vol. II, no. 19, Apr. 3 (1921): 4.

„La 4 august scriitorul norvegian împlineşte 70 de ani." Gazeta Noastră, vol. II, no. 87, Aug. 4 (1929): 9.

Langslet, Roar Lars. Hamsun Det skiftende spillets dikter. Oslo: Aventura Forlag, 1996.

Lupu, Ioan şi Cornelia Ştefănescu (coord). Bibliografia relațiilor literaturii române cu literaturile străine în periodice (1859-1918) - Literatura norvegiană. vol. I, Luminița Beiu-Paladi, Ana-Maria Brezuleanu, Catrinel Pleşu, Ileana Verzea. Bucureşti: Ed. Academiei Republicii Socialiste România, Institutul de Istorie şi Teorie Literară, 1980.

Marcu, P. „Pan, de Knut Hamsun. Aspecte contemporane.” Flacăra, vol.VIII, no. 6, Feb. 16 (1923): 115.

Mihăilescu, C. „Traducerile - cu prilejul Victoriei de Knut Hamsun.” Clipa (Bucureşti), vol. I, no. 28, Dec. 23 (1923): 1.

Narly, C. „Knut Hamsun.” Viața Literară, vol. I, no. 4, Mar. 13 (1926): 3.

Pas, Ion. „Foamea.” Lupta, vol. V, no. 1372, July 3 (1926): 1.

„Premiul Nobel pe 1919 - Cronică. Însemnări.” Luceafărul, vol. XV, no. 2-3, Feb. 1 (1920): 48.

Ralea, Mihai. „Knut Hamsun. Portret literar”. Însemnări Literare, vol. I, no. 33, Sept. 28 (1919): 13.

Săteanu, C. „Knut Hamsun: Păreri şi fapte.” Mişcarea, vol. XIII, no. 171, Aug. 23 (1919): 1.

Sletten Kolloen, Ingar. Hamsun Erobreren. Pössneck: Gyldendal NorskForlag, 2005.

„Ultima operă a lui Knut Hamsun.” Opinia, no. 4370, p. 1.

Zaciu, Mircea, Marian Papahagi şi Aurel Sasu. Dicționarul scriitorilor români, A-C. Bucureşti: Ed. Fundației Culturale Române, 1995.

Zaciu, Mircea, Marian Papahagi şi Aurel Sasu. Dicționarul scriitorilor români, D-L. Bucureşti: Ed. Fundației Culturale Române, 1998.

Zaciu, Mircea, Marian Papahagi şi Aurel Sasu. Dicționarul scriitorilor români, R-Z. Bucureşti: Ed. Fundației Culturale Române, 2002. 